DOI: 10.17707/AgricultForest.62.1.17

\begin{abstract}
Hakima OULEBSIR-MOHAND KACI, Souad TALBI-KHEMILI, Salima GANA-KEBBOUCHE, Bahia DOUMANDJI-MITICHE ${ }^{1}$
\end{abstract}

\title{
ANTAGONISTIC ACTIVITY OF TWO BACILLUS SP. STRAINS ISOLATED FROM AN ALGERIAN SOIL TOWARDS THE MIGRATORY LOCUST LOCUSTA MIGRATORIA (LINNAEUS 1758)
}

\begin{abstract}
SUMMARY
The aim of our study is to isolate, purify and characterize two entomopathogenic bacterial strains of the genus Bacillus from the soil of Adrar in the Algerian Sahara. The molecular characterization of the isolated strains was carried out by DNA isolation, PCR and sequencing of 16S rRNA gene, followed by a phylogenetic analysis. After that, the study of the bacteria toxicity on the fifth larvae stage of Locusta migratoria was conducted by assessing rates of mortality, $\mathrm{LT}_{50}$ and $\mathrm{LC}_{50}$. The phylogenetic analysis showed that the two strains (Strain-B1 and Strain -B2) were identified as Bacillus sp. (HE799656) and Bacillus sp. (HE805963), respectively, with a very high similarity (99\%) with the strains Bacillus thuringiensis (NR_043403) and Bacillus weihenstephanensis (NR_024697). Besides, the results of toxicity tests showed that larvae of L. migratoria are influenced by the two isolated bacterial strains. This action is more pronounced with the Bacillus sp. strain-B1 (HE799656) compared to Bacillus sp. strain-B2 (HE805963). Examination of $\mathrm{TL}_{50}$ shows that these times vary depending on the bacteria and concentrations applied. Similarly, the $\mathrm{LC}_{50}$ are closely related with time and they also vary depending on the bacterial strain tested.
\end{abstract}

Keywords: Locusta migratoria, Bacillus sp., larva-mortality.

\section{INTRODUCTION}

Among the locusts' enemies of Sahelian cultures, the migratory locust Locusta migratoria (Linnaeus, 1758) (Orthoptera, Acrididae) is the major pest invasion period. The damage is mainly limited to grass, increasing the risk of social erosion and poverty (Zakaria et al., 2003). The migratory locust occupies a very large geographical extension. Many subspecies have been described mainly in Africa, Madagascar, Oriental Asia, Australia and Mediterranean regions (Duranton et al., 1982).

\footnotetext{
${ }^{1}$ Hakima Oulebsir-Mohand Kaci, Souad Talbi-Khemili, Salima Gana-Kebbouche, (corresponding author: mohandkacihakima@yahoo.fr), Laboratory of Valorization and Conservation of Biological Resources, Department of Biology, Faculty of Sciences, University of M'hamed Bougara, Boumerdes, BP35000, ALGERIA, Bahia Doumandji-Mitiche 2Department of Agricultural and Forest Zoology, National Superior School of Agronomy, 16200 Algiers, ALGERIA Paper presented at the 6th International Scientific Agricultural Symposium "AGROSYM 2015". Notes: The authors declare that they have no conflicts of interest. Authorship Form signed online.
} 
Locust remains a major concern in the strategies of crop protection (Zakaria et al., 2003). However, current methods of control using insecticides are very effective in the desert but also harmful to many other animal species biotope and the environment. In this context, the use of insect microorganisms with insecticidal effects offers some potential (Joung \& Cote, 2000).

It is in this concept that this work falls. It aims to isolate bacterial strains belonging to Bacillaceae group, of the same biotope as the locust's, to assess their biological impacts on the later by determining the rate of mortality and calculating $\mathrm{LC}_{50}$ and $\mathrm{LT}_{50}$

\section{Soil sampling}

\section{MATERIAL AND METHODS}

Sampling was achieved from soil cultivated in the region of Adrar in the Algerian Sahara soil in September 2013. Samples were taken at the rhizosphere layer.

\section{Isolation, identification and characterization of bacterial strains}

Different soil samples are separately dried, screened and finely ground. Of each sample was weighed $10 \mathrm{~g}$ to suspend in $90 \mathrm{ml}$ of sterile physiological saline water, whilst stirring. Thereafter every suspension undergoes a series of decimal dilutions (10-1 to 10-5) (Guiraud, 2003). The purity is checked after each passage by microscopic examination of a smear stained with blue methylene and having undergone a Gram. The identification of purified isolates has been subject of a multiphase study, comprising a macroscopic, macroscopic, physiological, biochemical and molecular study of characters.

\section{Molecular identification}

DNA extraction, PCR and sequencing of 16S RNA

Extraction of DNA was performed as described by Ausubel et al. (1988). The extracted DNA is electrophoresed on agarose gel at $1 \%$ for 30 minutes under an electric current of $100 \mathrm{~V}$. The DNA was subsequently recovered from the agarose gel and purified using the Jetsorb extraction gel kit (Genomic DNA purification system-PROM, EGA).

The purified DNA is amplified by a Hot Start PCR $\left(94^{\circ} \mathrm{C}\right)$ using specific primers eubacterial $16 \mathrm{~S}$ rDNA primers (forward primer 5'AGAGTTTGATCCTGGCTCAG3' (Escherichia coli positions 8-27) and reverse primer 5'ACGGCTACCTTGTTACGACTT3' (E. coli positions 14941513) (Weisburg et al 1991). Each $50 \mu 1$ reaction volume is composed of $2 \mu 1$ of PCR buffer, $0.5 \mathrm{mM}$ of each primer, $1.5 \mathrm{mM} \mathrm{MgCl} 2,50 \mathrm{mM}$ of each deoxynucleoside triphosphate and $1 \mu 1$ of Taq polymerase.

The samples analyzed are deposited into the wells of $50 \mu$ PCR plates, installed in a thermocycler type Mastercycler Personal (Eppendorf, Germany). The following program was used: $95{ }^{\circ} \mathrm{C}$ for $1 \mathrm{~min}$, followed by 40 cycles of denaturation $\left(1 \mathrm{~min}\right.$ at $\left.95{ }^{\circ} \mathrm{C}\right)$, annealing $\left(1 \mathrm{~min}\right.$ at $\left.55^{\circ} \mathrm{C}\right)$ and polymerization $(2$ minutes at $72{ }^{\circ} \mathrm{C}$ ) for $5 \mathrm{~min}$. 
The amplification products are purified using the PCR DNA GFXTM Kit and Gel B and Purification Kit (Amersham Biosciences) then cloned into a vector based on the instructions of manufacturer's instruction (INST / AcloneTM PCR Product Cloning Kit, MBI Fermentas). Transformed clones were selected on LB medium containing ampicillin $(100 \mathrm{mcg} / \mathrm{ml})$ and X-gal $(80 \mathrm{mcg} / \mathrm{ml})$.

\section{Phylogenetic analysis}

The 16S rRNA gene sequences obtained after sequencing were subjected to a similarity search of sequences deposited in the Genbank database (on the NCBI National Center for Biotechnology Information website) using the BLAST program. The multiple sequence alignment was performed by CLUSTALW 1.8 (Thompson et al., 1994). The sequence homology was then evaluated and the phylogenetic tree was created by neighbor joining method (Saitou \& Nei, 1987) using the MEGA $_{5}$ software (Tamura et al., 2011). The confidence levels of the topology of the phylogenetic tree obtained were estimated by the analysis of data resampling methods (bootstrap) with 1000 replications.

\section{Evaluation of the toxicity of the bacteria on larvae $L_{5}$ of \\ Locusta migratoria}

Source of locusts

The study is performed on L5 larva of the species Locusta migratoria. These are captured in the desert of Algeria and put into mass breeding in the laboratory.

Preparation of bacterial suspensions and application of biological treatments

To highlight their entomopathogenic power towards the migratory locust, we have initially conducted the preparation of the mother-solutions. Successive dilutions are then prepared to $10^{-4}$ dilution. For the application of biological tests, 48 hours old larvae are treated after fasting for 24 hours orally (OulebsirMohandKaci, 2012).

\section{Calculation of mortality percentages}

The percentage of mortality observed in the control and treated larvae is calculated using the following formula:

Observed mortality $=($ Number of dead individuals $/$ Total number of individuals) $\mathrm{X} 100$

\section{Calculation of $L C_{50}$ and $L T_{50}$}

Before calculating the $\mathrm{TL}_{50}$, the percentage of observed mortality is corrected relative to the control in the form of ABBOT (1925).

To calculate the $\mathrm{LC}_{50}$ (concentration needed to kill half of a population) for each bacterium, we have transformed the concentrations used in logarithms and mortality percentages for corrected probits by using the table probit. The $\mathrm{LC}_{50}$ is determined from the equation of the regression line.

\section{Statistical analysis}

To confirm the effectiveness of the biological treatment performed, the results are subject to the test analysis of variance. We have applied the Tuckey. 
The software used is the XLSTAT.and clusters kept in Falcon tubes were placed inside the containers covered with transparent plastic bags and incubated in the greenhouse at $20-25^{\circ} \mathrm{C}$. Bags were removed after $48 \mathrm{~h}$ and symptoms were monitored daily for a week. Two fungal isolates which causes different disease severity on detached leaves was tested on clusters of Tombul hazelnut cultivar. Reisolations were performed.

\section{RESULTS AND DISCUSSION}

\section{Physiological and biochemical characterization of bacterial isolates}

The multiphase study, being initiated by exploring the macroscopic appearance of bacterial cultures grown on nutrient agar, has shown that isolates carrying the B1 and B2 codes provide well-isolated colonies, broad, smooth, flat, circulars, cream color with irregular edges. Observation under the light microscope of fresh cells and after simple staining with methylene blue and Gram stain, has shown that the two strains are Gram positive and are long stick shaped with square end. Alongside the microscopic study, malachite green staining revealed that both isolates have a spore form. The spore has an oval shape nondeforming center position. Moreover, isolates B1 and B2 have shown positive results for the test of catalase, nitrate reductase and mannitol-mobility. The results of the pyruvic acid derivatives appeared positive for the Voges Proskauer reaction and the two isolates show a positive response for the hydrolysis of starch, gelatin and casein. In contrast, strains B1 and B2 expressed negative hydrolysis test against the indole and the Simmons citrate, and strain-B2 had not hydrolyzed urea. Both strains showed growth after culture and incubation at $45{ }^{\circ} \mathrm{C}$, contrary to the incubation at $550 \mathrm{C}$ and $65{ }^{\circ} \mathrm{C}$ which showed negative results.

Isolates have all the cultural characteristics of the genus Bacillus already described by Brossard \& Terry (1984) and Euzeby (2007). The specific classification has helped join the two bacterial strains isolated from the ground of the Algerian Sahara to the genus Bacillus (Guiraud, 2003). Partial sequencing confirms this affiliation with a very high similarity to Bacillus thuringiensis (NR_0434030). Indeed, the majority of bacteria of the genus Bacillus live in the soil or they persist with their spores. These are bacteria from land who derive their nutritional needs from an organic matter, nitrogen and minerals present in the soil (Brossard \& Terry, 1984; Ashnaei et al., 2009).

\section{Phylogenetic analysis}

The phylogenetic position of the two strains (Strain and Strain-B1-B2) is represented in a phylogenetic tree drawn by the neighbor joining method (Figure 1). The bar represents one substitution per 100 nucleotides. Level nodes of the values indicate the probabilities calculated by bootstrap. The 16S rDNA sequences of the two strains were obtained with 760 and 1504 nucleotides and stored in the database EMBL / EBI under reference numbers HE799656 accessions and HE805963 for the strain B1 and B2, respectively. Sequence analysis of these two strains has shown they are related to organisms belonging 
to the family Bacillaceae. They are affiliated to the genus Bacillus showing very high sequence identity (99\%) with the strains Bacillus thuringiensis (NR_043403), Bacillus cereus AM7 (JQ435684), Bacillus weihenstephanensis (NR_024697.1) and Bacillus mycoides (NR_036880). The two strains are in the same cluster as that of Bacillus thuringiensis (NR_043403) and Bacillus cereus AM7 (JQ435684).

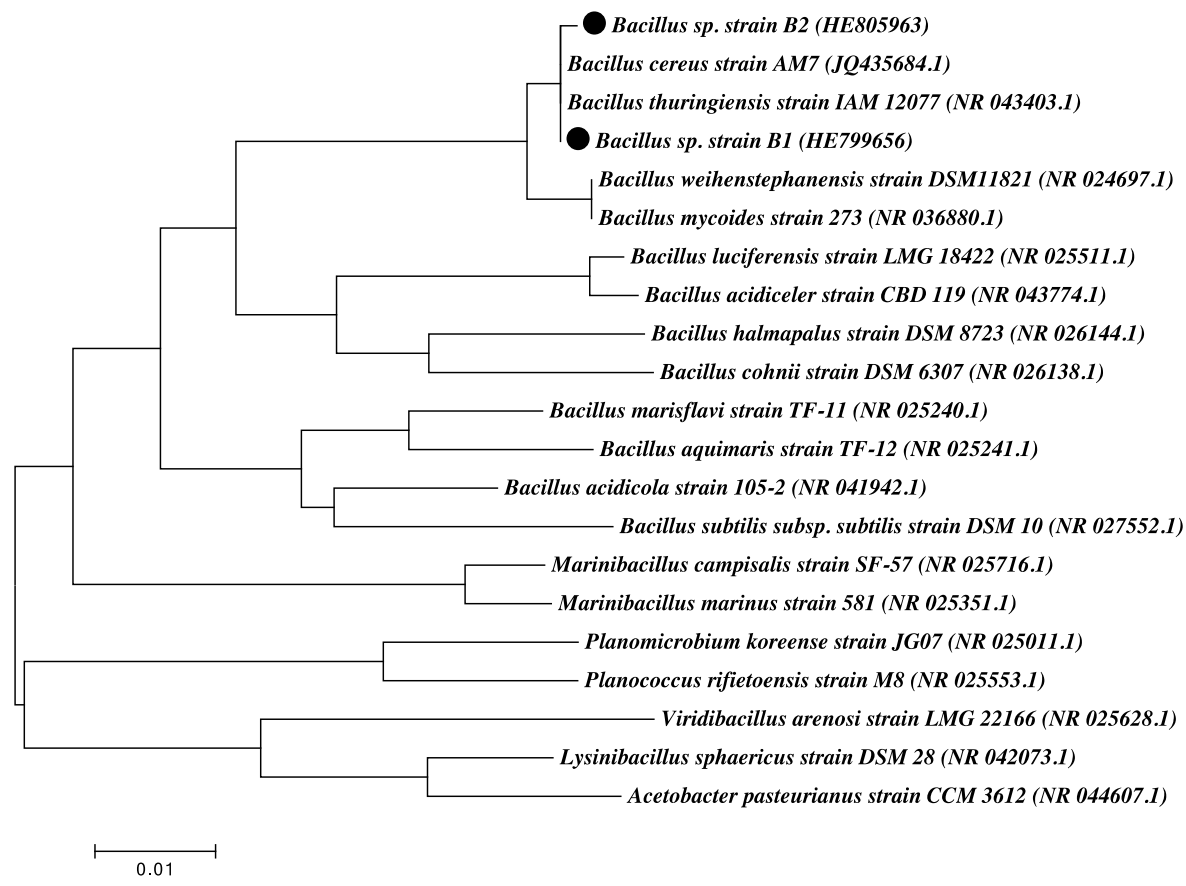

Figure 1: Phylogenetic tree drawn by Neighbor-Joining method of showing the phylogenetic position of strain-B1, strain-B2 and representatives of some other related taxa based on $16 \mathrm{~S}$ rDNA sequences.

\section{Evaluation of the toxicity of the bacteria on the larvae of L. migratoria}

Effect on Mortality

Within L5 larvae treated with Bacillus sp. strain-B1 (HE799656) (Figure 2 ), mortality reached $100 \%$ after 12 days after treatment at the high dose D1 and at 21 days after treatment at the intermediate dose D2 and finally $90 \%$ mortality obtained the same day after treatment with low doses D3. Similarly, mortality rates ranging from $86.67 \%$ after treatment with high dose to $70 \%$ after treatment medium and low dose of Bacillus sp. strain-B2 (HE805963) are achieved after 22 days (Figure 3). Analysis of variance revealed a very highly significant difference at $5 \%$ level $(\mathrm{P}<0.0001)$ between the control batch and the treated batch by both tested bacteria. Similarly, the Tukey test revealed significant differences for all combinations. 


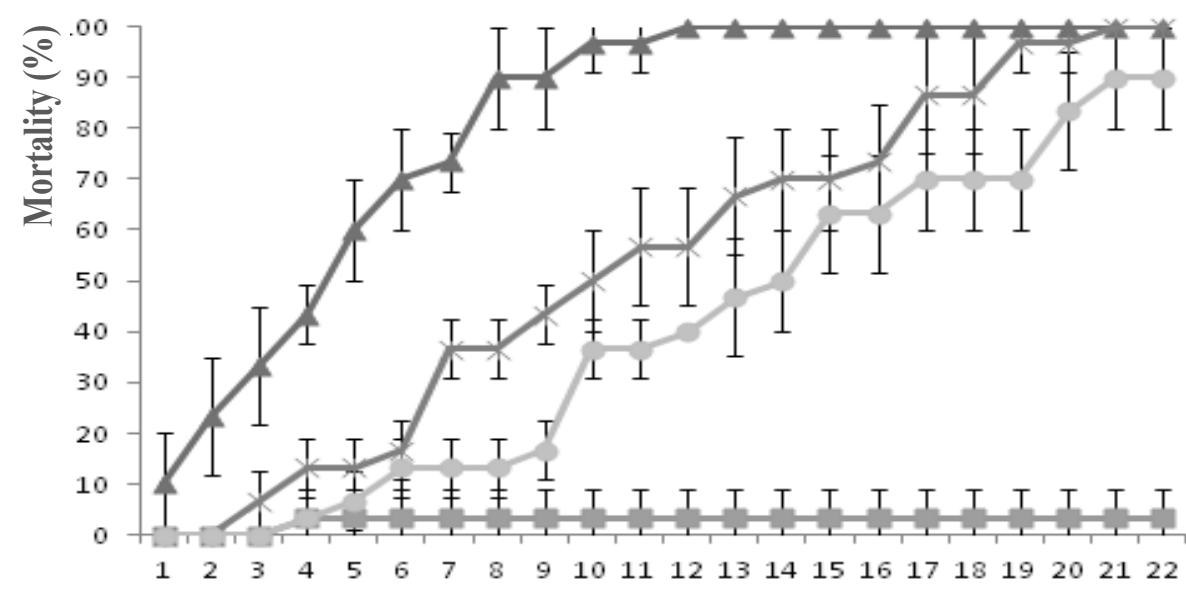

Time (days)

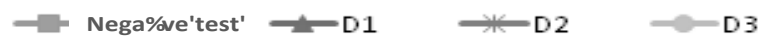

Figure 2: Cumulative daily mortality rate L5 larvae of $L$. migratoria treated with Bacillus sp. strain-B1 (HE799656) at doses D1 $=1.6 \mathrm{mg} / \mathrm{ml}, \mathrm{D} 2=$ $0.59 \mathrm{mg} / \mathrm{ml}, \mathrm{D} 3=0.33 \mathrm{mg} / \mathrm{ml}$.

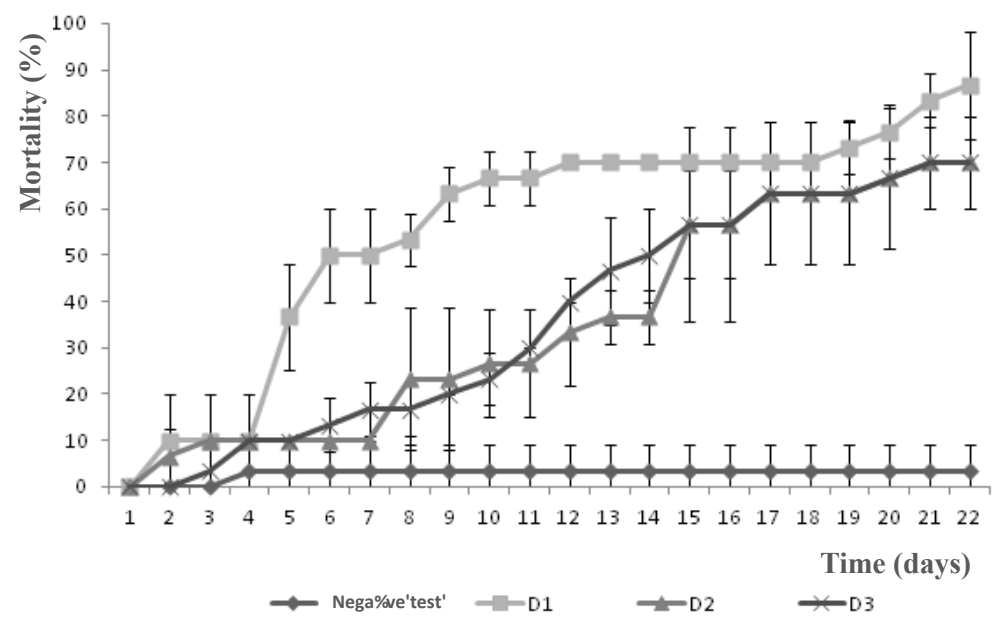

Figure 3: Cumulative daily mortality rate of L5 larvae of L. migratoriat reated with Bacillus sp. strain-B2 (HE805963) at doses D1= 1,67 mg/ml, D2=0,62 $\mathrm{mg} / \mathrm{ml}, \mathrm{D} 3=0,35 \mathrm{mg} / \mathrm{ml}$.

In the light of results, and for this parameter, it appears that larvae are influenced by our two bacterial strains. This action is faster with the strain bacillus sp. Strain-b1 (he799656) compared with bacillus sp. Strain-b2 (he805963). The terms of mortality vary between 12 and 22 days. This can be attributed to the mode of action of the majority of the genus bacillus bacteria 
which act by releasing toxins that demand special conditions or by the conditions of the intestinal environment of crickets that do not fit the growth and bacterial multiplication which requires a relatively long time adaptation (greathead et al., 1994; lacey et al., 2001). Indeed, the use of b. Subtilis, b. Thuringiensis and b. Larvae against larvae schistocerca gregaria, showed $90 \%$ mortality, $80 \%$ and $70 \%$ achieved after 16 days in 14 . However, pseudomonas aeruginosa has caused total mortality after 4 days (mohand-kaci \& doumandji-mitiche, 2006).

Finally, in a recent study, the effects of acute toxicity from topical application of growth regulators on three locusta migratoria var. Manilensis were evaluated in laboratory conditions with a recorded mortality rate of $97 \%$ for flufenoxuron, $100 \%$ for azadirachtin and $48 \%$ for pyriproxyfen (bi zhen et al., 2012).

\section{Calculation of $\mathbf{t l}_{50}$ and $\mathbf{l c}_{50}$}

Thus, the lethal time for $50 \%$ of individuals varies on the bacteria and the bacterial concentrations administered (figure 4). The 15 larvae of 1. Migratoria processed by bacillus sp. Strain-b1 (he799656) presented the lowest 1t50 with a value of 3.32 days recorded at the high dose, 9.12 days for the middle dose and 13.37 days for the low dose. They are followed by 15 larvae treated by bacillus sp. Strain-b2 (he805963) with 9.19 days for the high dose, 12.94 days for the intermediate dose and13.87 days for the low dose.

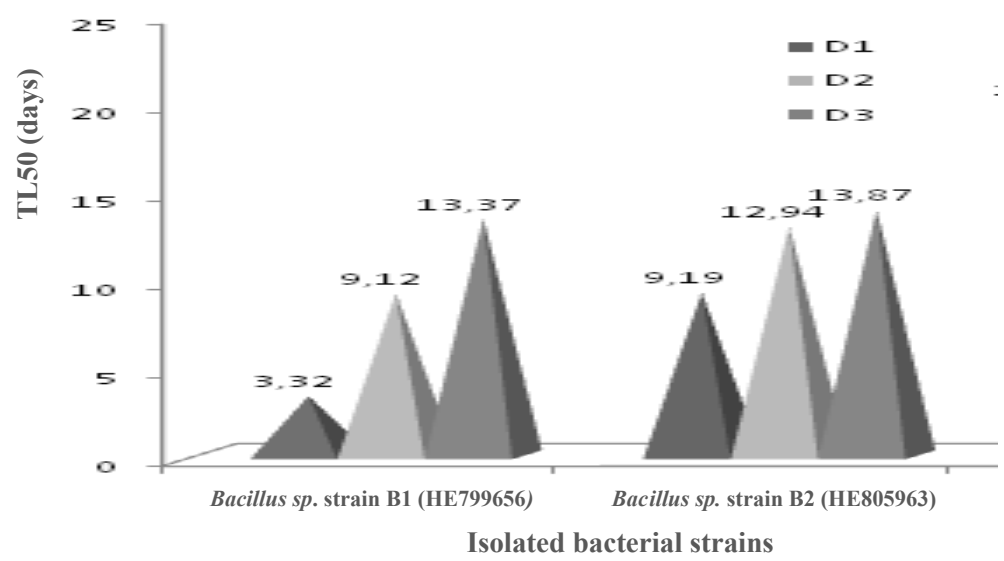

Figure 3: Cumulative daily mortality rate of L5 larvae of L. Migratoriat reated with Bacillus sp. Strain-B2 (HE805963) at doses D1= 1,67 mg/ml, $\mathrm{D} 2=0,62 \mathrm{mg} / \mathrm{ml}, \mathrm{D} 3=0,35 \mathrm{mg} / \mathrm{ml}$

In the light of results, and for this parameter, it appears that larvae are influenced by our two bacterial strains. This action is faster with the strain bacillus sp. Strain-b1 (he799656) compared with bacillus sp. Strain-b2 (he805963). The terms of mortality vary between 12 and 22 days. This can be attributed to the mode of action of the majority of the genus bacillus bacteria which act by releasing toxins that demand special conditions or by the conditions of the intestinal environment of crickets that do not fit the growth and bacterial 
multiplication which requires a relatively long time adaptation (greathead et al., 1994; lacey et al., 2001). Indeed, the use of b. Subtilis, b. Thuringiensis and b. Larvae against larvae schistocerca gregaria, showed 90\% mortality, $80 \%$ and $70 \%$ achieved after 16 days in 14 . However, pseudomonas aeruginosa has caused total mortality after 4 days (mohand-kaci \& doumandji-mitiche, 2006).

Finally, in a recent study, the effects of acute toxicity from topical application of growth regulators on three locusta migratoria var. Manilensis were evaluated in laboratory conditions with a recorded mortality rate of $97 \%$ for flufenoxuron, $100 \%$ for azadirachtin and $48 \%$ for pyriproxyfen (bi zhen et al., 2012).

\section{Calculation of $\mathbf{t l}_{50}$ and $\mathbf{l c}_{50}$}

Thus, the lethal time for $50 \%$ of individuals varies on the bacteria and the bacterial concentrations administered (figure 4). The 15 larvae of 1. Migratoria processed by bacillus sp. Strain-b1 (he799656) presented the lowest lt50 with a value of 3.32 days recorded at the high dose, 9.12 days for the middle dose and 13.37 days for the low dose. They are followed by 15 larvae treated by bacillus sp. Strain-b2 (he805963) with 9.19 days for the high dose, 12.94 days for the intermediate dose and13.87 days for the low dose.

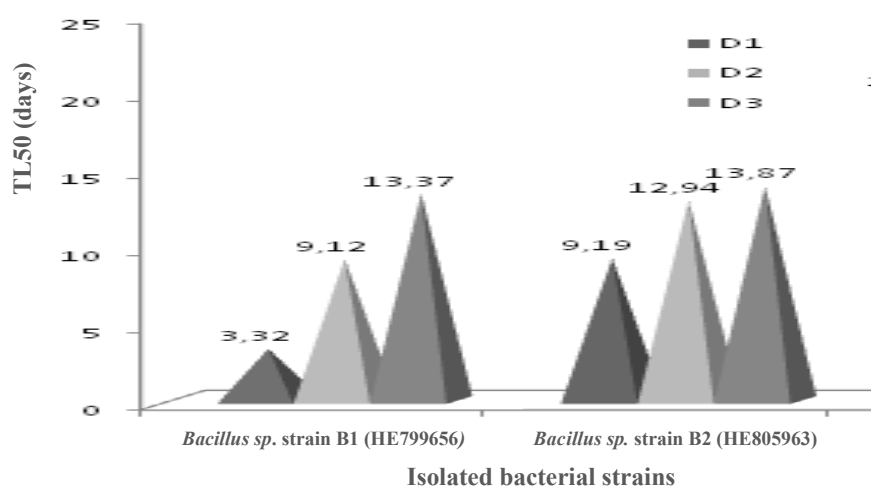

Figure 4: TL50 obtained for L5 larvae of L. migratoria treated with 3 concentrations of Bacillus sp. Strain-B1 (HE799656) and Bacillus sp. Strain-B2 (HE805963)

The comparison of LC50 obtained for mortality observation time for 5, 7 and 14 days after treatment shows that the LC50 is closely related with time; it varies depending on the tested bacterial strain (Figure 5). Indeed, the lowest LC50 are obtained at the 14th day with $0,37 \mathrm{mg} / \mathrm{ml}$ and0.62 $\mathrm{mg} / \mathrm{ml}$ for the strains Bacillus sp. strain-B1 (HE799656) and Bacillus sp. strain-B2 (HE805963). The higher $\mathrm{LC}_{50}$ are recorded on the 5 th day with values of 1.37 and $2.87 \mathrm{mg} / \mathrm{ml}$.

Furthermore, if one compares the lethal dose by ingestion of the different tested strains, we can see that the strain Bacillus sp. Strain-B1 (HE799656) shows considerably more effective and fast reaction than others. It presents the LC50, the lowest in all tested times (5, 7and 14 days after treatment). 


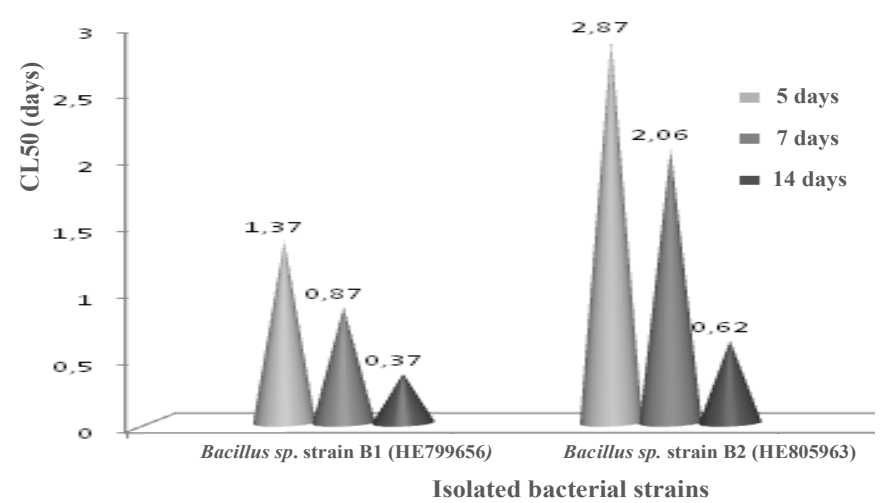

Figure 5: $\mathrm{CL}_{50}$ obtained for L5 larvae of L. migratoria treated with 3 concentrations of Bacillus sp. strain-B1 (HE799656) and Bacillus sp. strain-B2 (HE805963).

Our results agree with those of Ould El Hadj et al. (2006) which recorded a 7,5 days TL50 for L5 larvae Schistocerca gregaria treated with Neem, 8.2 days to 10.4 days for Melia and Eucalyptus. In addition, comparison of the sensitivity of Locusta migratoria to a commercial product and a local strain of Metarhizium showed that the latter has a higher activity with a pathogenic $\mathrm{TL}_{50}$ of 7.1 days (Niassy et al., 2011).

Gry et al. (1966) notes that the calculation of lethal doses determines the dose of the insecticide to be applied to the insect to obtain the desired percentage of mortality, allowing to judge accurately the insecticide product's power. The mortality rate in adult females of the mite Tetranychus urticae increased with increasing the concentration of conidia of two strains of entomopathogenic fungi and the most virulent against the mite was Paecilomycis fumosoroseus, having the lowest value of LC50 $\left(9.1 \times 10^{4}\right.$ conidia/ml $)$ and LT50 $\left(4.58\right.$ days to $1 \times 10^{8}$ conidia/ml) followed by Verticillium lecanii with an LC50 $\left(1.7 \times 10^{6}\right.$ conidia / $\mathrm{ml}$ ) and LT50 5.45 days $1 \times 10^{8}$ conidia / ml (Amjad et al., 2012).

\section{CONCLUSIONS}

In conclusion, despite the proven value of these biological control agents, it appears that they are not much used. Yet they seem to offer the best prospects for biological controls, especially those that can be formulated to be multiplied and spread like biopesticides, particularly during locust control campaigns where they help reducing the outbreak mass.

\section{REFERENCES}

Amjad, M., Hamid Bashir, M., Afzal, M., Altaf Sabri, M. \& Javed, N. 2012. Synergistic Effect of Some Entomopathogenic Fungi and Synthetic Pesticides, Against Two Spotted Spider Mite, Tetranychus urticae Koch (Acari: Tetranychidae). Pakistan Journal of zoology 44 (4): 977-984.

Ashnaei, SP., Sharifi, TA., Ahmadzadeh, M. \& Behboudi, K. 2009. Interaction of different media on production and biocontrol efficacy of Pseudomonas fluorescens P-35 and Bacillus subtilis B-3 against gray mould of apple. Journal of Plant Pathology 91: 65 70.

Ausubel, FM., Brent, R., Kingston, RE., Moore, DD., Seidelman, JG. \& Struhl, Ke. 1988. Current Protocols in Molecular Biology. - Wiley, New York. 
Bi-Zhen, H., Ying, X., Xiao-Rong, Z. \& Shi Wang-Peng, S. 2012. Molt disruption and mortality of Locusta migratoria var. manilensis (Meyen) (Orthoptera: Acrididae) caused by insect growth regulators. African Journal of Biotechnology 11(16) : 38823887 .

Brossard \& Terry 1984. Bactériologie systématique (systematic bacteriology). - Ed. C.R.D.P, Lyon, $220 \mathrm{p}$.

Duranton, JF., Launois, M., Launois-Luong, MH. \& Lecoq, M. 1982. Manuel de prospection acridienne en zone tropicale sèche (Locust prospecting manual in dry tropics). G.E.R.D.A.T, Paris.

Euzeby, JP. 2007. Dictionnaire de Bactériologie Vétérinaire.(Veterinary Bacteriology dictionary). www.bacdico.net.

Greathead, D., Kooyman, C., Launois-Luong, M. et Popov, G. 1994. Les ennemis naturels des criquets du sahel (The natural enemies of locusts of the Sahel). Coll. Acrid. Operat. $\mathrm{n}^{\circ} 8$. Ed. Cirad/Prifas. Montpellier, 85p.

Gry, J., Coquard, J. \& Coquard, G.1966. Appréciation en laboratoire de l'activité des insecticides à l'égard du criquet migrateur (Laboratory appreciation of the activity of insecticides against the migratory locust). L'agronomie tropicale (6-7)837-855.

Guiraud, JP. 2003. Microbiologie alimentaire; Application à l'étude des principaux groupes microbiens.(Food microbiology; Application to the study of the main microbial groups) - Ed. DUNOD, Paris, 651p.

Joung, J. \& Cote, JC. 2000. Une analyse des incidences environnementales de l'insecticide microbien Bacillus thuringiensis.( An analysis of the environmental impacts of the microbial insecticide Bacillus thuringiensis.) - Ed.AAC. Centre de recherche et développement en horticulture, Bulletin technique n.29, Canada.

Lacey, LA., Frutos, R., Kaya, HK. \& Vail, P. 2001. Insect Pathogens as Biological Control Agents: Do They Have a Future? Biological Control. 21 : 230-248 .Mohand Kaci, H. \& Doumandji-Mitiche, B. 2006. Evaluation of the biological impact of bacteria on desert locust pilgrim Schistocerca gregaria. - Ninth Arab Congress of Plant Protection, November 2006, Damascus, Syria.

Niassy, S., Diarra, K., Ndiaye, S. \& Niassy, A. 2011. Pathogenicity of local Metarhizium anisopliae var.acridum strains on Locusta migratoria migratorioides Reiche and Farmaire and Zonocerus variegates Linnaeus in Senegal. African Journal of Biotechnology 10(1) : 28-33.

Ould El Hadj, MD., Tankari Dan- Badjo, A., Halouane, F. \& Doumandji, S. 2006. Toxicité comparée de trois plantes acridifuges sur les larves du cinquème stade et sur les adultes de Schistocerca gregaria Forskål, 1775 (Orthoptera, Cyrtacanthacridinae) (Comparative toxicity of three acridifuges plants on the fifth instar larva and adults of Schistocerca gregaria Forskål, 1775 (Orthoptera, Cyrtacanthacridinae) . Séchresse 17(3): 407-414.

Oulebsir-Mohandkaci, H. 2012. Evaluation de l'impact biologique de quelques souches locales de Bacillus sp.et Pseudomonas spp. fluorescent vis à vis du criquet migrateur Locusta migratoria cinerascens (Orthoptera: Acrididae). (Evaluation of the biological impact of some local strains of Bacillus sp. and Pseudomonas spp. fluorescent against the migratory locust Locusta migratoria cinerascens (Orthoptera: Acrididae)). Thèse Doctorat: Inst. Nati. Agro., El Harrach, Alger. 187p.

Saitou, N. \& Nei, M. 1987. The neighbour-joining method: a new method for reconstructing phylogenetic trees. Molecular Biology and Evolution 4(4):406-25.

Tamura K., Peterson D., Peterson N., Steker G., Nei M., Kumar S., 2011. MEGA5:

Molecular evolutionary genetics analysis using maximum likelihood, evolutionary distance, and maximum parsimony methods. Mol. Biol. Evol.

Weisburg, WG., Barns, SM., Pelletier, DA. \& Lane, DJ. 1991. 16S ribosomal DNA for phylogenetic study. Journal of Bacteriology. 173: 697-703.

Zakaria, O. \& Sagnia, SB. 2003. Lutte intégrée contre les sautereaux et les locustes: importance du biopesticide Green Muscle (Integrated fight against grasshoppers and locusts: the biopesticide Green Muscle importance). - Bull. trimestriel d'information du Centre Régional AGRHYMET, 5 (3). 